\title{
Diet composition and prey selection of Telmatobius macrostomus, the Junín giant frog
}

\author{
Andrew S. Watson ${ }^{1, *}$, Austin L. Fitzgerald ${ }^{1}$, Oscar J. Damián Baldeón ${ }^{2}$ \\ ${ }^{1}$ Peace Corps Community-Based Environmental Management Program, Surco, Lima, Peru \\ ${ }^{2}$ Servicio Nacional de Áreas Naturales Protegidas por el Estado del Perú, Reserva Nacional de Junín, Junín, Peru
}

\begin{abstract}
This study describes the diet composition and prey selection of the Endangered Junín giant frog Telmatobius macrostomus, endemic to the central Andes of Peru. Prey items were recovered by forced regurgitation of stomach contents through gastric lavage. Top prey taxa in all samples $(\mathrm{n}=9$ ) consisted of a snail (Mollusca: Gastropoda: Hygrophila: Physidae; $78 \%$ frequency of occurrence) and an amphipod (Arthropoda: Malacostraca: Amphipoda: Hyalellidae; $56 \%$ frequency of occurrence). T. macrostomus appeared to select snails (family Physidae) and mayflies (family Baetidae) from the available prey in the environment. No vertebrate species were found in the stomach contents. Only 9 adults were found during this study (survey effort $=8.9$ person-hours per frog), suggesting that adults of this species are rare and/or difficult to find. Although our sample size is limited, and the results need to be interpreted with caution, these findings provide important basic ecological data that can prove useful in the conservation of this species.
\end{abstract}

KEY WORDS: Junín giant frog · Telmatobius macrostomus · Diet composition · Prey availability · Prey selection $\cdot$ Wildlife conservation

\section{INTRODUCTION}

The Junín giant frog Telmatobius macrostomus (Peters, 1873) is the largest completely aquatic frog, having maximum snout-vent lengths of $141.0 \mathrm{~mm}$ for males and $170.3 \mathrm{~mm}$ for females (Lehr 2005). It is endemic to the regions of Junín and Pasco in the central Andes of Peru at an elevational range of 3300 to $4600 \mathrm{~m}$ above sea level (Fjeldsa 1983). This species can be found in high Andean bodies of water such as rivers, streams, and lagoons, the most important being Lake Junín.

In 2004, the species was listed as Endangered in the IUCN Red List of Threatened Species and Critically Endangered on Peru's Instituto Nacional de Recursos Naturales website (Angulo et al. 2004, Angulo 2008). This frog faces a gamut of threats, including (1) overexploitation for human consumption, both as a source of protein and to prepare drinks

*Corresponding author: a.watson029@gmail.com with presumed medicinal properties (Lehr 2000, Angulo 2008); (2) habitat loss through the extraction of resources, mining pollution, eutrophication, overgrazing, and fluctuations in water levels controlled by the Upamayo dam (Shoobridge 2006); (3) introduction of the exotic rainbow trout Oncorhynchus mykiss; (4) disappearance of native fish of the genus Orestias (Becerra Díaz 2012); (5) emerging infectious diseases (chytridiomycosis and ranavirus) (Warne et al. 2016); and (6) climate change (Becerra Díaz 2012).

In the past, attempts at captive breeding of this species have been made; however, the captive breeding centers around the Junín National Reserve were closed in 2012 (Coronel \& Rojas 2014). Furthermore, attempts at captive breeding may have contributed to the decline of this species due to the high numbers of adults captured from the wild, with little success in its controlled reproduction (Arias Segura 2003). Knowledge of food requirements and environmental

() The authors 2017. Open Access under Creative Commons by Attribution Licence. Use, distribution and reproduction are unrestricted. Authors and original publication must be credited. 
conditions is essential for strengthening conservation efforts for this species (A. Salas unpubl. report 'Explotacíon y fomento de la rana B. macrostomus' to Viceministerio de Pesquería). As such, we examined diet composition and diet selection in relation to potential prey in T. macrostomus habitat.

A previous study of the Junín giant frog indicates that adults are carnivorous, feeding extensively on pupfish of the genus Orestias (Ayala 1977); unfortunately, no quantitative data exist on the abundance of this historically important prey taxa, only observational natural history notes. Therefore, this study may not reflect recent trends in prey abundance and availability due to decades of acid mine drainage from the Cerro de Pasco region via the San Juan river (Rodbell et al. 2014) and management of water levels controlled by the Upamayo dam (O'Donnel \& Fjeldsa 1997). The objectives of this study were to conduct a diet analysis of the Junín giant frog to determine important prey taxa and to identify what prey the frog is selecting from the environment.

\section{MATERIALS AND METHODS}

\section{Fieldwork and stomach content analysis}

Fieldwork was conducted within the Junín National Reserve $\left(10^{\circ} 59^{\prime} 15^{\prime \prime} \mathrm{S}, 76^{\circ} 06^{\prime} 31^{\prime \prime} \mathrm{W}\right)$, the Historic Sanctuary of Chacamarca, and the National Sanctuary of Huayllay, Peru, and their respective buffer zones (Fig. 1). We collected adults during monthly frog surveys from January 2015 to July 2016. Surveys consisted of twenty $100 \mathrm{~m}$ transects using 2 to 4 investigators moving in the upstream direction with dip nets and thoroughly searching all available refugia. Survey effort was 4 person-hours per transect, i.e. 2 investigators for $2 \mathrm{~h}$ or 4 investigators for $1 \mathrm{~h}$. Transects were selected throughout the study area based on accessibility and a categorical gradient from visually good to bad habitat (e.g. natural rivers to canals), which resulted in a variety of sampled habitats. Mean stream widths and depths ranged from 0.7 to 39.0 and 0.2 to $3.0 \mathrm{~m}$, respectively. All surveys were conducted during the day due to the difficulty of accessing remote locations at night. Upon capture, stomachs of adult frogs were flushed with a $60 \mathrm{cc}$ syringe and $4 \mathrm{~mm}$ tubing (Rice \& Taylor 1993). This non-lethal method was chosen to lessen the impacts of research activities on this threatened species. Stomach flushing has proven successful with crocodilians, lizards, turtles, frogs, and salamanders (Legler 1977, Legler \& Sullivan 1979, Fitzgerald 1989, Rice \& Taylor 1993, Bondi et al. 2015). Rice \& Taylor (1993) found that this method proved useful in obtaining dietary data on a broad size range of ranid frogs. All recovered stomach contents were preserved in 95\% ethanol for later analyses, and frogs were returned alive to their original habitat.

To estimate prey availability in the frogs' habitats, we sampled benthic macroinvertebrate communities where adult frogs were found. Additionally, presence/not found data of fish were recorded, although fish communities were unable to be quantified. At each site, 11 samples were obtained with a D-frame style dip/kick net (net dimensions $0.3048 \times 0.3048 \mathrm{~m}$ with $500 \mu \mathrm{m}$ mesh) using a modified version of the multi-habitat approach for low-gradient streams to sample a total of $1.0 \mathrm{~m}^{2}$ (WVDEP 2014). Samples were collected based on the proportion of habitat available in the $100 \mathrm{~m}$ transect (WVDEP 2014). All 11 samples were filtered through a $250 \mu \mathrm{m}$ sieve, combined into a single composite sample, and preserved in $95 \%$ ethanol (WVDEP 2014). To obtain a subsample that was both random and representative of the whole, we followed the US Environmental Protection Agency's Rapid Bioassessment Protocol. A subsample of 200 macroinvertebrates was

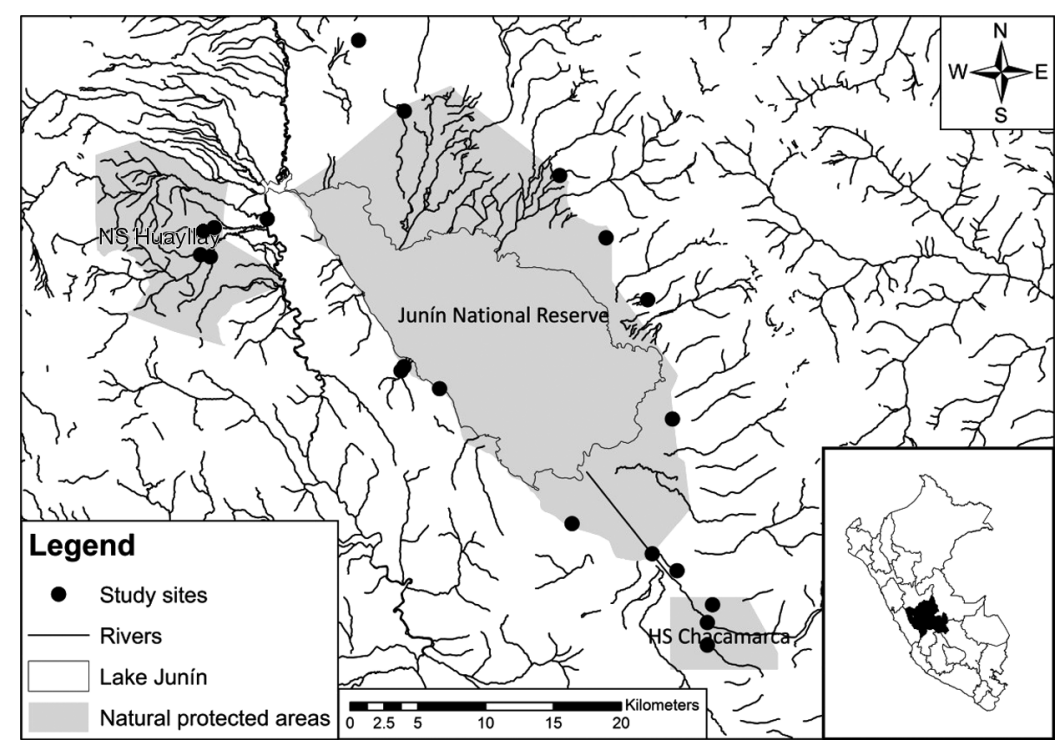

Fig. 1. Study sites within the Junín National Reserve, Historic Sanctuary (HS) of Chacamarca, and National Sanctuary (NS) of Huayllay, Peru, and their respective buffer zones 
obtained by picking individuals from randomly selected grid cells (WVDEP 2014). All stomach contents and potential prey were identified to family or the lowest possible taxonomic level using Domínguez \& Fernández (2009).

\section{Data analysis}

We quantified diet composition by calculating the percent by number, percent by mass, frequency of occurrence, and index of relative importance of each prey type. Percent by mass was calculated with average fresh weight estimates of macroinvertebrates from Morante et al. (2012), and the index of relative importance is a composite measure that reduces bias in descriptions of animal dietary data (Hart et al. 2002).

To determine what diet items the frogs might be selecting from their environment, we performed Pearson's chi-square test of independence, with statistical significance when $p<0.05$. Post hoc tests were used to determine which taxa were significantly different between numbers present in the habitat and numbers consumed. For this, Pearson's chi-square tests of independence for pairwise comparisons were made, with Bonferroni correction of the $\mathrm{p}$-value $(0.05 / 16=\mathrm{p}<0.0031 ; 16$ individual tests were run). All statistical analyses were conducted in the R statistical environment Version 3.0.2 (R Development Core Team 2013).

\section{RESULTS}

\section{Diet composition}

We examined the stomach contents of 9 Junín giant frogs. All samples contained identifiable remains of prey items $(\mathrm{n}=96)$ (Table 1$)$. Overall, prey from 9 taxonomic families were identified. Samples contained $2.8 \pm 1.6$ prey taxa (mean $\pm \mathrm{SD}$ ), and no samples had more than 6 taxa. Taxa most frequently consumed were snails (Mollusca: Gastropoda: Hygrophila: Physidae, Planorbidae; $51 \%$ in number and $87 \%$ in biomass).

\section{Prey selection}

Sixteen potential benthic macroinvertebrate prey taxa were collected, 9 of which were actually found in frog stomachs (Table 2). Additionally, 2 native fish genera (Orestias and Trichomycterus) were observed. Orestias was found at all sites where adult frogs occurred and most sites where adult frogs did not occur but were not present in frog stomachs (Table 2). There was a statistical difference in the composition of potential benthic macroinvertebrate prey and those consumed by frogs $\left(\chi^{2}=118.1, \mathrm{df}=15\right.$, $\mathrm{p}$-value $\left.=2.2 \times 10^{-16}\right)$. Subsequent pairwise comparisons found a statistical difference between snails (family Physidae) and mayflies (family Baetidae) present in the environment and consumed by frogs compared to all other benthic macroinvertebrates $\left(\chi^{2}=86.5, \mathrm{df}=1, \mathrm{p}\right.$-value $=2.2 \times 10^{-16}$ and $\chi^{2}=9.80$, $\mathrm{df}=1, \mathrm{p}$-value $=0.002$, respectively) (Table 2 ).

\section{DISCUSSION}

In this study, we related diet composition to prey availability and prey selection of the Junín giant frog. We found snails (family Physidae) to be the most prevalent prey taxon, composing $49 \%$ of the frogs' diet. Analyses also indicate that frogs may be selecting these snails from their environment.

During this study, we did not find any vertebrates in stomach contents; however, only 9 stomachs were

Table 1. Frequency of prey items (number of stomachs in which prey items were found and, in parentheses, percentage of the total number of stomachs examined); numbers of each prey item found (total no.) in all stomachs, with percentage (in parentheses) of total number of prey items; mass of prey items ( $g$, with percentage of total in parentheses); and index of relative importance (IRI) of each prey item in the diet of Telmatobius macrostomus. Values are based on the analysis of $\mathrm{n}=9$ stomachs

\begin{tabular}{|c|c|c|c|c|}
\hline Prey & Frequency & Total no. & Mass (g) & IRI \\
\hline Mollusca: Gastropoda: Hygrophila: Physidae & $7(78)$ & $47(49)$ & $4.14(82)$ & 1.02 \\
\hline Mollusca: Gastropoda: Hygrophila: Planorbidae & $2(22)$ & $2(2)$ & $0.23(5)$ & 0.01 \\
\hline Arthropoda: Malacostraca: Amphipoda: Hyalellidae & $5(56)$ & $30(31)$ & $0.52(10)$ & 0.23 \\
\hline Arthropoda: Insecta: Ephemeroptera: Baetidae & $3(33)$ & $3(3)$ & $0.02(0)$ & 0.01 \\
\hline Arthropoda: Insecta: Hemiptera: Corixidae & $3(33)$ & $8(8)$ & $0.11(2)$ & 0.03 \\
\hline Arthropoda: Insecta: Trichoptera: Hydroptilidae & $1(11)$ & $1(1)$ & $0.00(0)$ & 0.00 \\
\hline Arthropoda: Insecta: Coleoptera: Elmidae & $1(11)$ & $2(2)$ & $0.00(0)$ & 0.00 \\
\hline Arthropoda: Insecta: Diptera: Empididae & $1(11)$ & $1(1)$ & $0.01(0)$ & 0.00 \\
\hline Arthropoda: Insecta: Diptera: Chironomidae & $2(22)$ & $2(2)$ & $0.00(0)$ & 0.00 \\
\hline
\end{tabular}


Table 2. Numbers of potential prey (no. present) compared to prey consumed by Telmatobius macrostomus (no. consumed) and p-values from the post hoc Pearson's chi-square tests of independence for pairwise comparisons for each potential prey vs. all others, with Bonferroni correction of the p-value $(0.05 / 16=0.0031)$. Percentages $(\%)$ are shown in parentheses. Bold values indicate significance $(\mathrm{p}<0.0031)$. (-) data not available

\begin{tabular}{|c|c|c|c|}
\hline Prey & No. present & No. consumed & p-value \\
\hline Platyhelminthes: Turbellaria & $3(0.4)$ & 0 & 1.000 \\
\hline Annelida: Oligochaeta & $39(4.7)$ & 0 & 0.058 \\
\hline Mollusca: Gastropoda: Hygrophila: Physidae & 99 (11.9) & $47(49.0)$ & $<0.0031$ \\
\hline Mollusca: Gastropoda: Hygrophila: Planorbidae & $3(0.4)$ & $2(2.1)$ & 0.148 \\
\hline Mollusca: Bivalvia: Veneroida: Sphaeriidae & $6(0.7)$ & 0 & 0.872 \\
\hline Arthropoda: Malacostraca: Amphipoda: Hyalellidae & $226(27.1)$ & $30(31.0)$ & 0.463 \\
\hline Arthropoda: Ostracoda & $10(1.2)$ & 0 & 0.578 \\
\hline Arthropoda: Arachnida: Acari & $10(1.2)$ & 0 & 0.578 \\
\hline Arthropoda: Insecta: Ephemeroptera: Baetidae & $129(15.5)$ & $3(3.1)$ & 0.002 \\
\hline Arthropoda: Insecta: Hemiptera: Corixidae & $71(8.5)$ & $8(8.3)$ & 1.000 \\
\hline Arthropoda: Insecta: Trichoptera: Hydroptilidae & $49(5.9)$ & $1(1.0)$ & 0.080 \\
\hline Arthropoda: Insecta: Trichoptera: Leptoceridae & $1(0.1)$ & 0 & 1.000 \\
\hline Arthropoda: Insecta: Coleoptera: Elmidae & $89(10.7)$ & $2(2.1)$ & 0.012 \\
\hline Arthropoda: Insecta: Diptera: Empididae & $2(0.2)$ & $1(1.0)$ & 0.718 \\
\hline Arthropoda: Insecta: Diptera: Chironomidae & $100(12.0)$ & $2(2.1)$ & 0.006 \\
\hline Arthropoda: Insecta: Diptera: Ephydridae & $1(0.1)$ & 0 & 1.000 \\
\hline Chordata: Actinopterygii: Cyprinodontiformes: Cyprinodontidae: Orestias & - & 0 & - \\
\hline Chordata: Actinopterygii: Siluriformes: Trichomycteridae: Trichomycterus & - & 0 & - \\
\hline
\end{tabular}

analyzed, and a greater sample size, or sacrificing individuals for analyses may yield different results. One study found that stomach flushing is an effective non-lethal method to collect diet samples for a salamander, Plethodon cinereus, recovering all or most of the stomach contents $95 \%$ of the time, although the prey most frequently missed were larger-bodied prey (Bondi et al. 2015). For this study, we could not justify sacrificing individuals of this frog; thus, fish of the genera Orestias and Trichomycterus may have been missed, biasing our results. Furthermore, adult frogs proved difficult to find (8.9 person-hours per frog), limiting our sample size and impacting the meaningfulness of statistical tests. While these results should be interpreted with caution, they provide our best approximation on diet composition and prey selection for this species.

Since previous accounts document the principal food source of Telmatobius macrostomus as fish in the genus Orestias (Ayala 1977), other details may explain why we did not find Orestias in the frogs' stomach contents. Becerra Díaz (2012) states that one of the main threats to the Junín giant frog is the disappearance of Orestias. This may be the result of pollution and management of lake levels controlled by the Upamayo dam, where dry seasons and drawdown periods have led to desiccation of the main recruitment habitats for these fish, resulting in dieoffs (O'Donnel \& Fjeldsa 1997). The introduction of rainbow trout to the area may also be contributing to the disappearance of Orestias. Rainbow trout were introduced to the Ecuadorian Andes in 1920 (Crawford \& Muir 2008) and can now be found throughout much of South America. During monthly surveys, the stomach contents of 2 rainbow trout were analyzed, and Orestias was found present (A. Watson pers. obs.). Therefore, additional studies on the food habits of introduced rainbow trout and comparison with the Junín giant frog would be an important step in identifying potential impacts of this exotic species.

In conclusion, our results show that snails (family Physidae) are the most abundant prey taxa found in the stomachs $(n=9)$ of the Junín giant frog, and there is evidence to suggest preferential selection of these snails. To our knowledge, this is the first study that compares prey availability with prey taken by the Junín giant frog, providing insight into their feeding behavior. Understanding the food requirements of $T$. macrostomus in its natural habitat could aid in its conservation, as future efforts at captive breeding require this information for effective management and maintenance.

Acknowledgements. We thank Shannon Behmke for initiating the High-Andean Frog Conservation through the Capacity Building program; Winy Arias Lopez, Rolando Uribe de la Cruz, Luis Castillo Roque, and numerous volunteers for their help in field sampling; George T. Merovich Jr. for helpful comments on analyses; John R. Wallace for field and laboratory materials; Diego Shoobridge for his continuous support; 3 anonymous referees and responsible editor 
Michael Mahony for comments that improved the manuscript; and the Denver Zoological Foundation, Department of Conservation and Research, for field training and support. This work was funded in part by a Small Project Assistance grant from USAID and Servicio Nacional de Áreas Naturales Protegidas (SERNANP) por el Estado del Perú, specifically the Junín National Reserve and the Historic Sanctuary of Chacamarca.

\section{LITERATURE CITED}

Angulo A (2008) Conservation needs of Batrachophrynus and Telmatobius frogs of the Andes of Peru. Conserv Soc 6:328-333

Angulo A, Sinsch U, Aguilar Puntriano C (2004) Telmatobius macrostomus. The IUCN Red List of Threatened Species. 2004: e.T2645A9464237. http://dx.doi.org/10.2305/IUCN. UK.2004.RLTS.T2645A9464237.en (accessed on 9 June 2016)

Arias Segura CS (2003) Estado de conservación y análisis de los factores críticos para la viabilidad poblacional de Batrachophrynus macrostomus (Peters, 1873). BS thesis, Universidad Ricardo Palma, Lima

Ayala AI (1977) Determinación del régimen alimentario de la rana de Junín (B. macrostomus Peters 1873). BS thesis, Universidad Nacional Mayor de San Marcos, Lima

Becerra Díaz J (2012) Biología y conservación de la rana de Junín: Batrachophrynus macrostomus, Peters, 1873. Primera Edición Gobierno Regional Junín, Huancayo

Bondi CA, Green S, Beier CM (2015) Evaluation of gastric lavage method for diet analysis of the eastern redbacked salamander (Plethodon cinereus). Herpetol Rev 46:1-7

Coronel W, Rojas J (2014) Situación actual del Batrachophrynus macrostomus Peters para la conservación en la Reserva Nacional de Junín. BS thesis, Universidad Nacional del Centro del Perú, Huancayo

Crawford S, Muir A (2008) Global introductions of salmon and trout in the genus Oncorhynchus: 1870-2007. Rev Fish Biol Fish 18:313-344

Domínguez E, Fernández HR (2009) Macroinvertebrados bentónicos sudamericanos: sistemática y biología. Fundación Miguel Lillo, Tucumán

Fitzgerald LA (1989) An evaluation of stomach flushing

Editorial responsibility: Michael Mahony,

Callaghan, New South Wales, Australia techniques for crocodilians. J Herpetol 23:170-172

Fjeldsa J (1983) Vertebrates of the Junín area, central Peru. Steenstrupia 8:285-298

Hart RK, Calver MC, Dickman CR (2002) The index of relative importance: an alternative approach to reducing bias in descriptive studies of animal diets. Wildl Res 29: 415-421

Legler JM (1977) Stomach flushing: a technique for chelonian dietary studies. Herpetologica 33:281-284

Legler JM, Sullivan LJ (1979) The application of stomachflushing to lizards and anurans. Herpetologica 35: $107-110$

Lehr E (2000) Zur Nutzung einiger Amphibien- und Reptilienarten in Peru. Reptilia 24:40-46

Lehr E (2005) The Telmatobius and Batrachophrynus species of Peru. Monografías de Herpetología 7:39-64

Morante T, García-Arberas L, Antón A, Rallo A (2012) Macroinvertebrate biomass estimates in Cantabrian streams and relationship with brown trout (Salmo trutta) populations. Limnetica 31:85-94

O'Donnel C, Fjeldsa J (1997) Grebes-status survey and conservation action plan. IUCN/SSC Grebe Specialist Group, IUCN, Gland

R Development Core Team (2013) R: a language and environment for statistical computing. $\mathrm{R}$ Foundation for Statistical Computing, Vienna

Rice TM, Taylor DH (1993) A simple stomach flushing method for ranid frogs. Herpetol Rev 24:142-143

Rodbell DT, Delman EM, Abbott MB, Besonen MT, Tapia PM (2014) The heavy metal contamination of Lake Junín National Reserve, Peru: an unintended consequence of the juxtaposition of hydroelectricity and mining. GSA Today 24:4-10

Shoobridge D (2006) Protected area profile: Peru: Junin National Reserve: ParksWatch. ParksWatch Perú. http:// www.parkswatch.org/parkprofiles/pdf/jnar_eng.pdf (accessed on 3 January 2015)

Warne RW, LaBumbard B, LaGrange S, Vredenburg VT, Catenazzi A (2016) Co-infection by chytrid fungus and Ranaviruses in wild and harvested frogs in the tropical Andes. PLOS ONE 11:e0145864

WVDEP (West Virginia Department of Environmental Protection) (2014) Benthic invertebrate sampling, processing, and analysis: standard operating procedures. WVDEP, Charleston, WV

Submitted: August 10, 2016; Accepted: October 31, 2016

Proofs received from author(s): January 20, 2017 